\title{
DECISION-MAKING AND MANAGEMENT OF PRE-INVESTMENT IN A PROGRAMME OF PROJECTS
}

\author{
${ }^{1}$ R.P. Botha and ${ }^{2}$ H. Steyn \\ ${ }^{1,2}$ Graduate School of Technology Management \\ University of Pretoria, South Africa \\ ${ }^{1}$ rbotha@hatch.co.za, ${ }^{2}$ herman.steyn@up.ac.za
}

\begin{abstract}
Owing to ever-increasing business pressures and the resulting requirements of organisations, individual projects rarely fulfil all expectations; so it is quite often necessary to implement a programme of interdependent projects. In such programmes the matter of pre-investment (investing effort or money before the project results are required) is a recurring theme amongst programme managers. However, very few decision-making techniques or management guidelines on the topic of pre-investment are available. In this paper a framework is proposed to assist a programme or project manager in the decision-making and management of pre-investment in a programme. The framework is based on pre-investment propositions with high levels of support from a Delphi panel, in the context of a multi-billion Rand petrochemical programme. The results of the research are three matrices that provide guidance on the timing of pre-investment, tools and information required, and benefits of pre-investment. These guidelines all relate to four aspects of pre-investment: context, systems and procedures, timing, and scope. Even though the work was done in the context of a specific case, the preinvestment guidelines should be applicable in various industries.
\end{abstract}

\section{OPSOMMING}

Die steeds toenemende druk op besighede en die gevolglike vereistes wat ondernemings aan hulself stel, lei daartoe dat individuele projekte selde aan al die verwagtings voldoen. Dit is dus dikwels nodig om 'n program van interafhanklike projekte te implementeer. In sulke programme is voorafinvestering (investering van fondse of werk voordat projekresultate vereis word) 'n saak wat by herhaling deur programbestuurders opgehaal word. Daar bestaan egter tans geen besluitnemingstegnieke of riglyne vir die bestuur van voorafinvestering nie. Hierdie artikel behandel 'n raamwerk om programbestuurders en projekbestuurders behulpsaam te wees met besluitneming oor en die bestuur van vooraf-investering. Die raamwerk is gebaseer op proposisies ten opsigte van vooraf-investering met ' $n$ hoë vlak van aanvaarding van 'n Delphi paneel, in die konteks van 'n multi-biljoen Rand petrochemiese program. Die navorsing het drie matrikse opgelewer wat riglyne verskaf vir die tydsberekening vir vooraf-investering, hulpmiddels en inligting wat vereis word, en die voordele van vooraf-investering. Al hierdie riglyne hou verband met vier aspekte van vooraf-investering: konteks, stelsels en prosedures, tydsberekening, en bestek. Alhoewel die werk gedoen is in die konteks van 'n spesifieke geval, behoort die riglyne toepassing te vind in verskeie bedrywe.

\footnotetext{
${ }^{1}$ The author was enrolled for an M Eng (Project Management) in the Department of Engineering and Technology Management, University of Pretoria.
} 


\section{INTRODUCTION}

The standards of yesterday hardly fulfil the requirements of today. Due to the 'continuous improvement' expectations of businesses and customers, solutions to their problems are also becoming increasingly complex. Stretched targets of companies in a competitive environment require more ingenious and complex solutions. This suggests that one single project rarely meets all the business/client requirements, and therefore has to be combined with other projects to meet all expectations. Simply executing individual projects without exploiting synergies will rarely suffice. The solution's whole needs to be more than the sum of its parts; and so logic dictates that the projects need to be linked interdependently to achieve these stretched targets. Such inter-dependent projects are commonly known as programmes. Pellegrinelli (2002) supports this by stating that programmes provide a bridge between projects and the organisation's strategy.

For the sake of clarity, two definitions for a programme of projects are quoted: Pellegrinelli (1997) in Waddell (2005) defines a programme as: "projects managed in a coordinated way, either to achieve a common goal, or to extract benefits which would otherwise not be realised if they were managed independently", while Ferns (1991) describes programme management as "the coordination of projects to gain benefits that would not be possible to obtain were the projects managed separately".

Understanding the fundamental differences between project management and programme management is crucial to all managers who are moving from a project management arena to a programme management arena. One aspect that has a direct impact on the economics of the programme and of the company is the issue of financial pre-investment. The principles of time, value of money, and opportunity cost can lead to significant capital savings when the investment strategy and timing within a programme is optimised.

It is therefore necessary to identify when pre-investment would be required during a programme, and to have guidelines available to assist one in pre-investment decisions. Before continuing further, the term 'pre-investment' should also be clarified. The concept is illustrated by the following example:

When a newly-wed couple buys a four-bedroom house while thinking of starting a family in the future, it is considered pre-investment. Even though the couple only needs a one- or two-bedroom house, they invest financially in a larger property before they need the additional space.

For the purposes of this paper, 'pre-investment' is defined as: "The act of investing a portion of time, money, or effort before that particular portion of the investment is required, i.e. pre-emptively".

As a rule, resources and time can normally be expressed in monetary terms; therefore, in this study, only financial pre-investment was investigated. 


\subsection{Research objective}

A literature review conducted for this research revealed that the subject of financial pre-investment on programmes of projects is not sufficiently addressed in the literature. This implies a lack of guidance when decisions need to be made regarding pre-investment during the lifecycle of a programme. The objective of this study is therefore to establish a guideline to determine when pre-investment would be required on a programme, which factors would indicate the requirement for preinvestment, and what the benefits of such pre-investments would be.

\section{PRE-INVESTMENT}

When journal papers were reviewed to search for pre-investment related topics, no unified theory that addresses the approach (and consequences) of pre-investment in both projects and programmes was found. The literature study, which included the PMBOK (Project Management Institute, 2004), the Project Management Institute's (PMI's) Standard for Programme Management (2006), and a number of journal papers, revealed no direct mention of pre-investment as described earlier in this paper, nor of any pre-investment models. However, the literature review did indicate indirectly that there are various issues that could influence and complicate pre-investment decisions on projects and programmes. Such indicators were (for example) factors such as the form of the programme (Maylor et al., 2006), characteristics of the projects within the programme (Dietrich \& Lehtonen, 1995), timing of investments (Wambach, 2000; Joaquin et al, 2001), and project selection decision tools (Hamilton, 2002; Ghasemzadeh et al., 2000; and Shen et al., 2002), to name but a few.

The lack of guidance on the topic of pre-investment, combined with the direct monetary impact on business, clearly indicated that some management model, theory, or method is required. Since the surveyed literature did not address the issue of pre-investment, the researcher had to rely on inferred information and knowledge, and utilise a logical deductive approach to form a new set of propositions regarding pre-investment in a programme of projects.

Despite the lack of information on pre-investment in journals and the PMl's guides, issues, tasks, prerequisites, and reminders were mentioned in the published articles that, even though the literature did not focus on pre-investment, did manage to shed some light on pre-investment aspects. From the literature survey, financial pre-investment issues can be categorized into the following four aspects:

1. Context (of the programme and the particular pre-investment decision)

2. Systems and procedures (i.e. governance)

3. Timing/planning

4. Scope (i.e. size and complexity)

It is possible to create more classifications, but for the sake of simplicity, these four categories were used as the basis for this research. Based on these categories, 57 propositions relating to various aspects of pre-investment were developed. The validity of the propositions was tested by means of the Delphi technique (discussed later). 
The purpose of this research was to expand the present knowledge base of preinvestment and to provide guidelines for managerial decision-making.

\section{RESEARCH METHODOLOGY}

This inquiry into the phenomenon of pre-investment posed exploratory research questions, which called for a case study approach. Furthermore, a case study is the preferred research strategy for examining contemporary events when the relevant behaviours cannot be manipulated (Yin, 2004). The petrochemical programme investigated presents all the conditions required for the application of a case study approach: (1) the author has no control over events, (2) the focus of the programme is current (i.e. contemporary), and (3) the research raises exploratory research questions.

A multi-billion Rand programme of interdependent projects was executed to expand the total capacity of a specific petrochemical plant. The projects included in the programme encompassed the whole value chain, from raw material to delivery of final product to retailers. The scope of facilities and capital values of the subprojects also stretched over a considerable range, from simple piping modifications costing a few hundred thousand Rand, up to multiple reactor installations costing over a billion Rand.

Case study research relies on many of the same techniques as historical research, but requires two sources of evidence: direct observation and systematic interviewing. A number of interviewing methods exist, one of which is the Delphi method. Given the limited amount of information available on the topic of preinvestment, it was clear from the outset that the research method and approach would lend itself towards an exploratory study as well as the accumulation of expert opinions through the use of the Delphi technique.

With the choice of a case study underpinned by the Delphi technique, the following research plan was followed:

1. Review of literature regarding programme management and pre-investment

2. Highlighting the fundamental factors that influence financial pre-investment

3. Developing propositions relating to the various facets of pre-investment

4. Performing Delphi evaluation Round 1 to evaluate correctness of propositions

5. Performing Delphi evaluation Round 2, inherent to the Delphi process

6. Data analysis - evaluate the pre-investment propositions from the information gathered through the Delphi technique

7. Reaching conclusions on the applicability of the propositions on preinvestment, using the Delphi results to develop a pre-investment framework.

The Delphi technique is a qualitative research method, and therefore many criticise it as not being empirically verifiable. In order to understand better the Delphi technique as research method, and its applicability to this research, a literature review was done on the technique. The objective of the literature study was (1) to confirm the suitability of the Delphi method to test the validity of a number of preinvestment related propositions, and (2) to assess the various aspects of the Delphi 
process. After evaluation of the process, it was applied as prescribed by Delbecq et al. (1975). Key aspects of the Delphi process were:

- $\quad$ The content of the questionnaire was based on the propositions developed from the literature review.

- $\quad$ The panel of experts consisted of a wide range of disciplines and expertise. Fifteen respondents were approached, and 13 took part in the first round.

- $\quad$ The first questionnaire asked individuals to assess the validity of 57 preinvestment related propositions (forced Likert scale), followed by three open ended questions.

- The second questionnaire incorporated the feedback from the first questionnaire. Owing to the relatively low number of participants, it was possible to customise the second round of questionnaires for each participant.

- $\quad$ Both consensus and disagreements on the various propositions were valuable to the formulation of a pre-investment framework.

- $\quad$ From the data analysis a unified pre-investment decision guideline was formulated and discussed.

The panel of respondents were selected based on their extensive experience in the field of project and programme management, and relevant qualifications. Their positions within the company ranged from junior management to executive level, with more than 12 decades of combined work experience in the field of project/programme management. The approximate combined value of projects and programmes currently under their leadership is in excess of R60 billion (about $\$ 10 \mathrm{bn})$. All panel members are graduate engineers, with the majority of them having a secondary qualification such as an MBA or engineering masters' degree in technology management.

\section{RESULTS}

During the two-round Delphi process, the participants were asked to evaluate the correctness of 57 pre-investment related propositions, developed as part of this research.

\subsection{Data gathered}

The raw data gathered were in the form of a Likert scale rating of the 57 preinvestment propositions, as well as three paragraph answers from the open-ended questions.

Results obtained from the first Delphi round were analysed on a high level to assess the level of consensus amongst the Delphi panel members, before continuing with the Delphi process. If the data from the first round had been entirely divergent, $a$ different approach to the research study would have been considered. Fortunately, the first round promised good results, and a second round of the Delphi process was executed. The response rates for both Delphi round questionnaires were as illustrated in Table 1. 


\begin{tabular}{|c|c|c|c|}
\hline Questionnaire & $\begin{array}{l}\text { Number of } \\
\text { Participants }\end{array}$ & $\begin{array}{c}\text { Number of Returned } \\
\text { Questionnaires }\end{array}$ & Response Rate \\
\hline Delphi Round 1 & 15 & 13 & $87 \%$ \\
\hline Delphi Round 2 & 13 & 12 & $\begin{array}{c}92 \% \text { of Round } 2 \\
80 \% \text { of total }\end{array}$ \\
\hline
\end{tabular}

\section{Table 1: Questionnaire response rates}

Given the relatively small panel size, a high response rate was required to ensure the quality of the data gathered. The response rates in Table 1 indicate that this was achieved. Since there were minimal changes in the data after the second round, a third round was considered unnecessary.

\subsection{Presentation of data from both Delphi rounds}

The number of propositions with high consensus support after the first round was 19 , while the number of propositions with high consensus rejection after the first round was 6 . This was a total of $49 \%$ of tested propositions with clear, unanimous consensus. During the first round, no further analysis of the data was performed owing to the limited value of any calculations on an interim set of data.

After the second round, the number of propositions with high consensus support increased to 24 (compared with 19 in the first round). The number of propositions with high consensus rejection - 6 after the first round - increased to 13 after the second round. This was a total of $72 \%$ of tested propositions with clear, unanimous consensus.

The high level of consensus on the propositions during the first Delphi round indicated a high probability that the development of a framework for preinvestment would be feasible. Similarly, with the open-ended questions consensus was obtained on matters regarding pre-investment in a programme of projects.

With this quality of information available, the foundation was laid for further analysis of the raw data in order to extract and develop a solid framework for the decision-making and management of pre-investment. This is discussed below.

\subsection{Data analysis of Likert scale data}

There is generally no right or wrong way to analyze data from Likert-type items; the objective is to answer the research questions meaningfully (Adams et al., 1965). The methods of choice in analyzing Likert-type items should be statistical procedures that answer the research questions meaningfully, maintain the richness of the data, and are not subject to scaling debates. Given that the Likert scale data was ordinal in nature, arithmetic operations were impossible, thus restricting this data type to logical operations. Ordinal data is commonly tabulated and can be turned into percentages for comparison. Owing to the nature of the Likert questionnaires and answers, the responses to the first section of the questionnaire were identified and treated as ordinal data. 
For this particular research and Likert questionnaire, the levels of agreement and/or disagreement with a number of pre-investment propositions were measured, in order to assess the suitability of using those propositions in subsequent theorybuilding of a pre-investment decision and guidance framework. To fulfill this function, the following data analysis methods were decided upon:

- $\quad$ Reduction to nominal level, by combining all 'agree' and 'disagree' responses into two categories, 'accept' and 'reject'.

- $\quad$ Percentage tables:

- Response spreads per propositions

- Percentage propositions with high levels of consensus for/against the proposition

- Qualitative analysis of bipolar response spreads

Since the data obtained were not categorical and demographically related, crosstabulation was considered neither applicable nor necessary. All calculations required for the analysis mentioned above were done using Microsoft Excel.

\subsubsection{Data analysis of ordinal (Likert-obtained) data}

Likert scales may be subject to distortion for several reasons. Respondents may (1) avoid using extreme response categories (central tendency bias); (2) agree with statements as presented (acquiescence bias); or (3) try to portray themselves or their organization in a more favourable light (social desirability bias) (Wikipedia, 2007). The authors believe that all three factors were mitigated in this particular research by the following actions: (1) implementing a 4-point forced Likert scale, (2) asking questions in the reverse, and (3) participants completing questionnaires in isolation from other participants.

Reduction to the nominal level (first analysis method of choice) combined all 'agree' and 'disagree' responses into two categories, 'accept' and 'reject'. A proposition was considered 'accepted' when more than $50 \%$ of the respondents 'agreed' or 'strongly agreed' with the pre-investment statement, and vice versa. The split is illustrated in Table 2.

Acceptance of proposition

31 propositions, i.e. $61 \%$
Rejection of proposition

20 propositions, i.e. $39 \%$

\section{Table 2: Reduction from ordinal data to nominal 'agree' and 'reject' data}

Next, the percentage spread of answers for each Likert question was calculated. Owing to the size of the table it is not included in detail here. From this percentage spread of answers, a slightly more detailed analysis was done to highlight the individual propositions with a high level of consensus for or against them. Again, the quantification of 'high levels of support/rejection' was difficult, and was therefore classified according to the following two levels:

- ' 'Two thirds majority' = more than $66 \%$ in favour of or against proposition.

- $\quad$ 'Unanimous' $=90 \%$ or more in favour of or against proposition. 
Table 3 shows the summary results of the analysis.

\begin{tabular}{|c|c|c|}
\hline Level of consensus & $\begin{array}{c}\text { Number of } \\
\text { propositio } \\
\text { ns }\end{array}$ & $\begin{array}{c}\% \text { of total } \\
\text { number of } \\
\text { propositions }\end{array}$ \\
\hline 'Two thirds majority' support of proposition & 29 & $57 \%$ \\
\hline 'Unanimous' support of proposition & 24 & $47 \%$ \\
\hline $\begin{array}{l}\text { 'Two thirds majority' disagreement with } \\
\text { proposition }\end{array}$ & 19 & $37 \%$ \\
\hline 'Unanimous' disagreement with proposition & 13 & $25 \%$ \\
\hline $\begin{array}{l}\text { Consensus (either for or against) but not } \\
\text { overwhelming }\end{array}$ & 4 & $8 \%$ \\
\hline \multicolumn{3}{|l|}{ Neither significant support nor disagreement } \\
\hline Even spread of answers & 7 & $14 \%$ \\
\hline Bimodal distribution of answers & 3 & $6 \%$ \\
\hline
\end{tabular}

Table 3: Summary of Likert data analysis

Further attention was given to the pre-investment propositions with neither significant support nor disagreement. The even spread of responses was obtained mostly because of case-study specific issues (differing opinions within the Sasol company). It is the authors' assumption that these particular propositions would have different response spreads in another environment or organisational structure. The bimodal responses clearly showed the different focus and priority areas between the project (contractor) personnel and the plant production (client) personnel. Such differences in opinions were to be expected, but this bimodal pattern was present for relatively few of the questions.

\subsection{Data analysis of qualitative data}

The second half of the Delphi questionnaire contained three open-ended questions, which had the aim of obtaining qualitative data on a few important pre-investment facets. Only a few simple data clean-up and aggregation techniques were required to obtain very useful data. In the second Delphi round (where a first draft of consolidated answers was supplied for further comments), almost no additional comments were added by the respondents. This outcome showed that a high-quality and comprehensive list of pre-investment aspects was captured in the open-ended questions.

With the consolidated qualitative answers and the outcomes from the Likert questions data analysis, the stage was set to develop a framework for decisionmaking and management of pre-investment on a programme of interdependent projects.

\subsection{Pre-investment framework}

A framework for decision-making and management of pre-investment on a programme of interdependent projects that answers the research questions should contain guidelines on the following aspects: 
- When pre-investment is required, including the difference between preinvestment on projects vs programmes.

- What information and decision tools should be in place to be able to make good pre-investment decisions.

- $\quad$ Understanding the quality and type of benefits of pre-investments.

As described earlier, the literature indicated that the following four aspects are vital to the successful management of pre-investment: (1) Context in which preinvestment is made; (2) systems and procedures (i.e. governance); (3) timing/planning; and (4) scope (i.e. size and complexity).

It was only logical that guidelines regarding decision-making and management of pre-investment had to be divided into the same categories when answering the three research questions listed above. To enable a programme manager (or project manager of a project within a programme) to make the best possible pre-investment decisions, the various pre-investment aspects and research questions must be presented in a way that easily guides the manager in his/her decisions. A preinvestment decision and management guideline in the form of three matrices was developed to illustrate the pre-investment aspects relevant to the research questions.

The information used for the pre-investment matrices was based on both literature study and analysed data. These data were mapped on to the tree research questions to address the following items:

- General information

- Decision guidance

- Factors influencing aspects of pre-investment, relevant to the particular research question

The final resultant matrices for decision-making and management of pre-investment are provided in the Appendix.

The decision and guidance matrices provide insight into the subject of preinvestment. These three matrices contain a substantial amount of information, yet are simple to use during decision-making.

\section{CONCLUSIONS AND RECOMMENDATIONS}

A literature survey uncovered a deficient knowledge area, viz. the subject matter of pre-investment. This study offers some insight into the subject of pre-investment, and provides frameworks that are easy to utilize in decision-making.

The end result of the research is captured in three practical decision and guidance matrices, which include knowledge on a number of aspects of pre-investment.

Though the research was based on a case study within a petrochemical programme, the research results seem to be applicable in other project environments. This arises from the fact that the proposed guidelines contain no reference to the specific organisation or systems. 
In a few areas within the matrices (such as pre-investment timing guidance from company governance) information is still lacking. These deficiencies resulted either from the case study context or from the nature of the particular combination of fields. This can only be clarified by future research. Another topic for future research is to verify the extent to which these results can be generalised in industries other than the petrochemical industry.

\section{REFERENCES}

[1] Adams, E.W., Fagot, R.F. \& Robinson, R.E. 1965. A theory of appropriate statistics, Psychometrika, 30: 99-127.

[2] Delbecq, A.L., Van de Ven, A.H., Gustafson, D.H. 1975. Group techniques for program planning: A guide to nominal group and Delphi processes. Glenview, Illinois: Scott, Foresman.

[3] Dietrich, P. \& Lehtonen, P. 2005. Successful management of strategic intentions through multiple projects - Reflections from empirical study, International Journal of Project Management, 23: 386-391.

[4] Ferns, D.C. 1991. Developments in programme management, International Journal of Project Management, 9: 148-156.

[5] Ghasemzadeh, F. \& Archer N.P. 2000. Project portfolio selection through decision support, Decision Support Systems, 29: 73-88.

[6] Hamilton, A. 2002. Considering value during early project development: A product case study, International Journal of Project Management, 20: 131136.

[7] Joaquin, D.C. \& Khanna, N. 2001. Investment timing decisions under threat of potential competition: Why firm size matters, The Quarterly Review of Economics and Finance, 41: 1-17.

[8] Maylor, H., Brady, T., Cooke-Davies, T. \& Hodgson, D. 2006. From projectification to programmification, International Journal of Project Management, 24: 663-674.

[9] Pellegrinelli, S. 2002. Shaping context: The role and challenge for programmes, International Journal of Project Management, 20: 229-233.

[10] Pellegrinelli, S. 1997. Programme management: Organising project based change. International Journal of Project Management, 15(3).

[11] Project Management Institute. 2003. A Guide to the Project Management Body of Knowledge, $3^{\text {rd }}$ edition. Newton Square, Pennsylvania: PMI.

[12] Project Management Institute. 2006. Standard for Program Management, $1^{\text {st }}$ edition. Newton Square, Pennsylvania: PMI. 
[13] Shen, Q. \& Chung, J.K.H. 2002. A group decision support system for value management studies in the construction industry, International Journal of Project Management, 20: 247-252.

[14] Waddell D. 2005. Program management: The next step in the evolution of project management?, Problems and Perspectives in Management, 3: 160168.

[15] Wambach, A. 2000. Payback criterion, hurdle rates and the gain of waiting, International Review of Financial Analysis, 9: 247-258.

[16] Yin, K.R. 2004. Case study research: Design and methods. $2^{\text {nd }}$ edition. Sage Publications: New Delhi. http://en.wikipedia.org/wiki/Likert_scale, accessed on 10 August 2007. 


\begin{tabular}{|c|c|c|c|c|c|}
\hline & & Context & $\begin{array}{c}\text { Systems \& Procedures (i.e. } \\
\text { Governance) }\end{array}$ & Timing \& Planning & $\begin{array}{c}\text { Scope (i.e. Size \& } \\
\text { complexity) }\end{array}$ \\
\hline 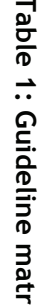 & एٓं & $\begin{array}{l}\text { General Information: } \\
\text { A project that can be postponed allows } \\
\text { learning more about a potential project or } \\
\text { product and market outcomes. }\end{array}$ & $\begin{array}{l}\text { General Information: } \\
\text { Systems \& Procedures (i.e. } \\
\text { company/project governance) usually do } \\
\text { not influence the timing of pre- } \\
\text { investments. However, governance } \\
\text { guidelines by default are set up such } \\
\text { that pre-investment is not allowed due } \\
\text { to the higher risk involved with such } \\
\text { investments. }\end{array}$ & $\begin{array}{l}\text { General Informaiton: } \\
\text { Decisions regarding pre-investment are made very early in the program life } \\
\text { cycle. Pre-investment decisions and cash flows can be earlier than Gate } 2 \\
\text { for critical pilot and demo testing projects. The majority of decisions are } \\
\text { made during the "Program Set-Up" phase, i.e. Gate 1-2. Decisions in this } \\
\text { phase will determine the requirements for the next phase. Further } \\
\text { optimization decisions (in terms of pre-investment) are done during the } \\
\text { program set-up phase, i.e. Gate } 2-3 \text {. The timing of delivery of scopes and } \\
\text { resource allocation will be determined during this stage. Between Gate } 2 \\
\text { and } 3 \text {, one would know both the overall and incremental benefits as well as } \\
\text { defining certain sub-projects scope, cost and time lines. This also } \\
\text { contributes to "scope freeze" which is imperative. The actual cash-flows } \\
\text { resulting from the pre-investment decisions will occur between Gate } 3 \text { and } \\
4 \text { (Delivering the Incremental Benefits phase) }\end{array}$ & \begin{tabular}{|l} 
General Information: \\
A program has a higher level of \\
complexity than a normal \\
project due to interdependency \\
of sub-projects. Therefore, more \\
time has to be spent evaluating \\
and deciding on pre-investment \\
in a program than on a single \\
project of similar capital value.
\end{tabular} \\
\hline 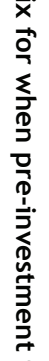 & 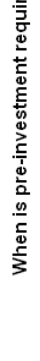 & $\begin{array}{l}\text { Decision Guidelines: } \\
\text { Context matters which must be taken into } \\
\text { account when making pre-investment } \\
\text { decisions are: } \\
\text { 1) Market demands } \\
\text { 2) Competitive forces } \\
\text { 3) Strategic fit of the program into the } \\
\text { company }\end{array}$ & $\begin{array}{l}\text { Decision Guidelines: } \\
\text { No pre-investment decision guidelines } \\
\text { are forthcoming from company systems } \\
\text { or procedures }\end{array}$ & $\begin{array}{l}\text { Decision Guidelines: } \\
\text { 1) Projects not bringing in additional benefits by itself should be done as } \\
\text { late as possible, while projects creating benefits by itself should be done } \\
\text { as early as possible. } \\
\text { 2) Due to the interdependencies between projects, one will require to have } \\
\text { certain projects completed earlier in order to give insight on the design } \\
\text { basis of another "successor" project. } \\
\text { 3) The critical path determines when revenue will start to flow (ramp-up of } \\
\text { benefits); therefore, managing the critical path (timing of cost flow) is } \\
\text { critical for optimising the rate of return of a program. } \\
\text { 4) Pre-investment decisions (regarding both timing and scope) must be } \\
\text { made before detail planning of the program has been cone. } \\
\text { 5) The planning of sub-projects and the decision of how to pre-invest can } \\
\text { be done multiple times during the program lifecycle. } \\
\text { 6) Limited resource availability is a legitimate reason why a project may be } \\
\text { forced to be implemented earlier or later than originally planned. } \\
\text { 7) The best available project management services is required during the }\end{array}$ & $\begin{array}{l}\text { Decision Guidelines: } \\
\text { No pre-investment timing } \\
\text { guidelines are forthcoming from } \\
\text { project scope matters }\end{array}$ \\
\hline 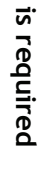 & & $\begin{array}{l}\text { Context factors influencing timing of } \\
\text { pre-investment: } \\
\text { The following program context factors } \\
\text { could influence the timing of pre- } \\
\text { investments: } \\
\text { 1) Market demands } \\
\text { 2) Competitive forces } \\
\text { 3) Strategic fit of the program into the } \\
\text { company }\end{array}$ & $\begin{array}{l}\text { Governance factors influencing } \\
\text { timing of pre-investment: } \\
\text { No factors influencing pre-investments } \\
\text { are forthcoming from company systems } \\
\text { or procedures }\end{array}$ & $\begin{array}{l}\text { Factors influencing timing of pre-investment: } \\
\text { 1) Resource availability. In order to balance engineering resources } \\
\text { especially project implementation resources, construction and } \\
\text { manufacturing it may be neccessary to complete some part earlier or later. } \\
\text { 2) Early needs for capacity/throughput/benefits } \\
\text { 3) Shutdown or maintenance intervals/timing on existing or affected } \\
\text { facilities }\end{array}$ & $\begin{array}{l}\text { Scope factors influencing } \\
\text { timing of pre-investment: } \\
\text { No factors influencing pre- } \\
\text { investments are forthcoming } \\
\text { from project scope matters }\end{array}$ \\
\hline
\end{tabular}




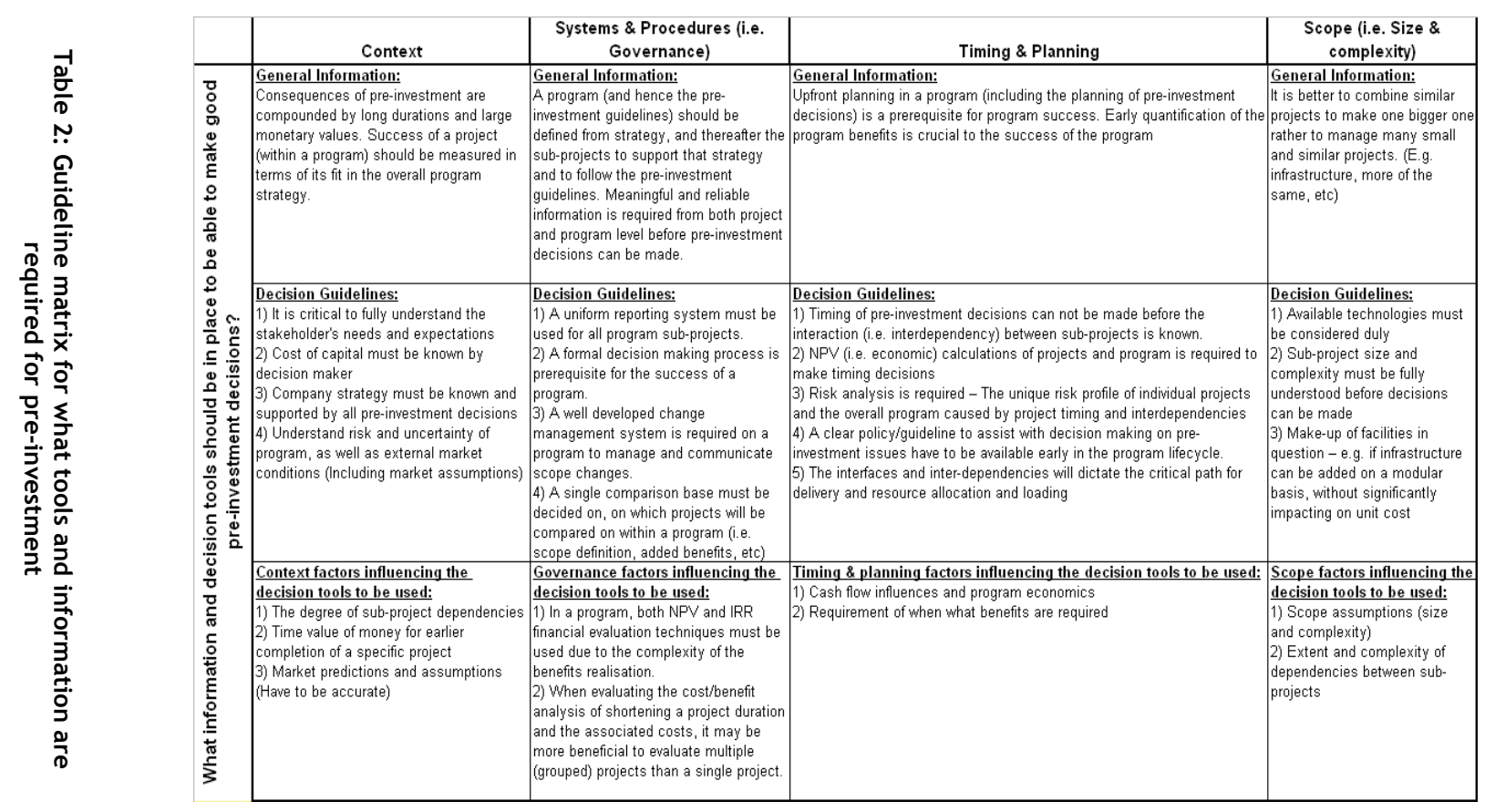




\begin{tabular}{|c|c|c|c|c|}
\hline & Context & $\begin{array}{c}\text { Systems \& Procedures (i.e. } \\
\text { Governance) }\end{array}$ & Timing \& Planning & $\begin{array}{l}\text { Scope (i.e. Size \& } \\
\text { complexity) }\end{array}$ \\
\hline \multirow{3}{*}{ 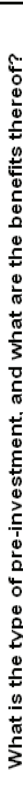 } & $\begin{array}{l}\text { General Information: } \\
\text { Due to the long durations of large } \\
\text { programs, programs have to be flexible to } \\
\text { accommodate any changes in market } \\
\text { conditions that happen over time }\end{array}$ & $\begin{array}{l}\text { General Information: } \\
\text { Governance requirements may influence } \\
\text { the type of pre-investments open to an } \\
\text { organisation, and hence the associated } \\
\text { benefits }\end{array}$ & $\begin{array}{l}\text { General Information: } \\
\text { No factors influencing type or benefits of pre-investments are forthcoming } \\
\text { from timing \& planning matters }\end{array}$ & $\begin{array}{l}\text { General Information: } \\
\text { The only type of benefit } \\
\text { obtained from variances in } \\
\text { scope is economy of scale, for } \\
\text { both procurement and } \\
\text { production activities. }\end{array}$ \\
\hline & $\begin{array}{l}\text { Pre-investment benefits, stemming } \\
\text { from context matters: } \\
\text { 1) It gives momentum to the execution } \\
\text { team } \\
\text { 2) It allows for future growth and flexibility, } \\
\text { should it be required. } \\
\text { 3) It opens opportunities for which the } \\
\text { future is not } 100 \% \text { clear at this stage. } \\
\text { 4) It initiates "out of the box" thinking then } \\
\text { facilities are unavailable: } e \text {.g. when a road } \\
\text { is built, businesses/shops follow, not the } \\
\text { other way around. } \\
\text { 5) It commits the company to further } \\
\text { development }\end{array}$ & $\begin{array}{l}\text { Pre-investment benefits, stemming } \\
\text { from governance matters: } \\
\text { 1) Optimisation of resource utilization } \\
\text { by spreading workload out by starting } \\
\text { early or late, i.e. could improve (lessen) } \\
\text { strain on resources. Also reduce } \\
\text { competition of recourses. Furthermore, } \\
\text { it frees up resources for other projects } \\
\text { in the program. }\end{array}$ & $\begin{array}{l}\text { Pre-investment benefits, stemming from timing \& planning matters: } \\
\text { 1) If one pre-invests correctly, real money spinners (individual projects) } \\
\text { later in the program won't be constrained by common facilities } \\
\text { 2) Pre-investment enables an "early as possible" ramp-up of benefits } \\
\text { 3) If pre-invested facilities could be applied earlier, it could add economic } \\
\text { benefit through the time value of money and faster pay-back periods } \\
\text { 4) Pre-investment early in program reduces workload and schedule at the } \\
\text { end of the program } \\
\text { 5) If you have to wait for all the answers to make a "normal" business } \\
\text { investment decision, the program will never be implemented, therefore pre- } \\
\text { investment is needed. }\end{array}$ & \begin{tabular}{|l|} 
Pre-investment benefits. \\
stemming from scope \\
matters: \\
1) Pre-investments can exploit \\
economy of scale benefits \\
2) Better integrated design (vs. \\
multiple add-ons) are possible \\
ihrough pre-investments \\
3) Pre-investment eliminates \\
duplication of facilities
\end{tabular} \\
\hline & $\begin{array}{l}\text { Context factors influencing the type or } \\
\text { benefit of pre-investment: } \\
\text { 1) It might be required to pre-invest on a } \\
\text { sub-project to enable synergistic } \\
\text { negotiations with large vendors/suppliers, } \\
\text { especially if the market is very competitive } \\
\text { 2) When benefits are uncertain, } \\
\text { investments should be committed in } \\
\text { stages, thus retaining the option to } \\
\text { abandon at different stages while retaining } \\
\text { the ability to grow } \\
\text { 3) Economic climate, which can be either } \\
\text { constructive or destructive to pre- } \\
\text { investment decisions }\end{array}$ & $\begin{array}{l}\text { Governance factors influencing the } \\
\text { type or benefit of pre-investment: } \\
\text { No factors influencing type or benefits of } \\
\text { pre-investments are forthcoming from } \\
\text { governance matters }\end{array}$ & $\begin{array}{l}\text { Timing \& planning factors influencing the type or benefit of pre- } \\
\text { investment: } \\
\text { 1) Requirement of sequence (and size) of benefits realization. }\end{array}$ & $\begin{array}{l}\text { Scope factors influencing the } \\
\text { type or benefit of pre- } \\
\text { investment: } \\
\text { 1) The amount of pre-investment } \\
\text { is dependent on how much } \\
\text { overlap exists between the } \\
\text { different sub-projects. } \\
\text { 2) Economy of scale benefits }\end{array}$ \\
\hline
\end{tabular}

